\title{
Five things government can do to encourage local food contingency plans
}

\author{
Kimberley Reis* \\ School of Environment and Science, Griffith University, Brisbane, Australia
}

(Received 1 March 2018; final version received 19 October 2018)

\begin{abstract}
Severe weather events pose significant risks to food supply chains that are reliant upon critical infrastructures such as road and rail. Can local food procurement arrangements, and contingency plans based on those arrangements, help to ameliorate food shortage in times of crisis? This article explores how governments can empower communities to this end. A broader research project provides the basis of insights and recommendations to aid policy practitioners who seek to develop food-related disaster resilience at the community level. The findings call for the following: the adoption of policies that facilitate the procurement of local food; informing council planning; facilitating shared control with those who want these changes to occur; removing the barriers to change; and utilising a suite of consultation and engagement policies to these ends. It is argued that the Australian regional context of South-East Queensland, with its inherent issues of rapid population growth, has immediate relevance to international contexts.
\end{abstract}

Keywords: local food procurement; contingency plans; disaster resilience; risk perceptions; governance

\section{Introduction}

Queensland is a State in the north-eastern corner of Australia that experiences severe climate-related events such as cyclones, flood, bushfires and droughts (Howes et al. 2012). These events commonly interrupt critical infrastructures, such as road and rail, upon which food supply is dependent. The South-East Queensland region has one of the highest population growth rates in the country, placing even greater reliance on uninterrupted supply of food using those road and rail links. Emergency Management Queensland (EMQ) is the state department for managing re-supply to isolated communities. Under the Queensland Re-supply Guidelines, the term "isolated community re-supply" is activated when residents have: "ready access to retail outlets however the retail outlet is unable to maintain the level of essential goods required due to normal transport routes being inoperable as a result of a natural event(s)" (EMQ 2012, 2). Given the interdependence of the transport network: "distance is not considered an isolating factor if such communities... are accessible by road, rail or water transport" (EMQ 2012, 21). It is recommended that "communities should not become reliant on re-supply operations, and should make every effort to become self-sufficient in all their needs in case they become isolated" (EMQ 2012, 2).

*Email: k.reis@griffith.edu.au 
In the light of this, contingency plans are developed to manage the risks of disruptive events in unusual circumstances. Contingency plans aim to make decisions in advance of an emergency to coordinate the timely management of better preparation for, and recovery from, potential impacts (IFRC 2012). For example, if food could not be supplied to retail outlets within three days, decisions made in anticipation of such an event will enhance preparation, and therefore recovery, from those otherwise negative impacts. Three days is how long Queenslanders are advised to be self-sufficient until assistance arrives (QRA 2017). Under the Queensland Re-supply Guidelines, the current scope for individual and community preparations for food survival is confined to stockpiling sufficient longer shelf-life food items and making arrangements with local suppliers for extended lines of credit (EMQ 2012). Drawing from the support of family and the wider community is also a hallmark of a community's resilience to food shortage (Reis 2013)

These contingency arrangements, however, have varying degrees of success in delivering food security. The Food and Agriculture Organisation of the United Nations (FAO) widely accepted features of food security intends that: "Food security exists when all people, at all times, have physical, social and economic access to sufficient, safe and nutritious food which meets their dietary needs and food preferences for an active and healthy life" $(2018,1)$. The FAO further advises that adequate quantity, quality and diversity of food must be available with ongoing and stable access to that food, in terms of how it is supplied and how it is used.

In times of food shortage, people can become food insecure in spite of well-intentioned efforts to stockpile, arrange lines of credit and draw on wider-reaching support. Food insecurity can arise due to the following: experiencing hunger or food insufficiency; feelings of worry about having to use food relief; or feelings of anxiety about acquiring food or of running out of that food (Reis and Ferreira 2015). In contrast, Crowe and Smith $(2012,169)$ found that:

Communities with values and beliefs conducive for community betterment (cultural capital) coupled with acting on those beliefs through participation in civic groups and networking with outside communities and organizations (social capital) are much more likely to have a variety of sources of food than communities with low levels of cultural and social capitals.

Local food procurement plans and contingency arrangements based upon them are an example of this. Cultural capital in this context refers to the emerging "spaces of solidarity" that underpin the values of broader participation and inclusiveness in procuring food from local sources (Sonnino 2017, 5). Such spaces often acknowledge that diverse values and preferences in relation to food are also important cultural capitals (Kato and McKinney 2015). In this way, one person's feeling of food security may, in another person, lead to feelings of anxiety. The social capital, or broader reach, is found not only in the bonds or social ties that underpin the common goal but the member's efforts to bridge relationships with like-minded groups who share in the common goal (Pooley, Cohen, and Pike 2005).

These social and cultural capitals underpin local food procurement and contingency planning. However, these plans fall outside the formal policy landscape for food re-supply (Reis 2013). The rise of local food plans, whether driven by interest groups or councils, is a global movement. These plans often aim to address food shortage and feelings of food insecurity by drawing upon these capitals (Campbell 2009; Parfitt et al. 2012; Creative 
Commons 2011; PHAA 2009; TFSC 2012). In doing so, a variety of urban food production sites in the South-East Queensland, both regional and global, address the call for sustainability and climate change adaptation (Reis and Ferreira 2015; Guitart, Byrne, and Pickering 2015).

The local food planning movement coincides with the disaster resilience movement that recognises the increasing complexities due to climate changes. The global community has undergone a shift towards longer-term planning horizons for building resilience to severe weather events. Because of the widespread and pervasive nature of critical infrastructure dependencies, and their associated vulnerabilities, a trend towards better preparation for disaster events, particularly at the community level, has been evidenced in Australia (e.g. AIDR 2018; Green Cross 2018; QCOSS 2012). The trend resonates well with the advent of community food planning. Australia's national response to the international push for disaster resilience is the National Strategy for Disaster Resilience: Building our nation's resilience to disasters (NSDR), adopted by the Council of Australian Governments (COAG) in 2011. The NSDR's agenda is for a shared responsibility (COAG 2011, 7) whereby:

Leaders drive development of partnerships and networks to build resilience at the government, business, neighbourhood, and community levels. These partnerships are based on a sense of shared responsibility and an acknowledgement of the need for coordinated planning and response.

This call is based upon the need for a "better understanding of the risk environment and disaster impacts, and an adaptive and empowered community that acts on this understanding" (COAG 2011, 3). Such a call falls well within the remit of local food procurement planning. Based on a broader research project, this article discusses one question that arose to address this need: What can government do to facilitate local food contingency plans? The first section examines how understandings of the risk environment are shaped by the perceptions of Policy Networks (i.e. the government and industry bodies that form food procurement policy) and Governance Networks (i.e. the more informal networks of groups engaged with community-based food procurement). The broader study from which this article has emerged is then outlined. Finally, five actions that governments can do to facilitate local food contingency plans are then discussed in terms of original interview data generated from the broader study.

\section{Adaptive communities acting on their understanding of the risk environment}

The research problem revealed by a review of the literature on food-related disaster events in South-East Queensland demonstrated concerns about the interplay between the following: the needs of a rapidly growing urban population; the need for our current food supply chain model to function uninterrupted; and climate change impacts on the critical infrastructure needed for this model to function (Reis 2013). Compounding this, the Australian Academy of Science states that this region can expect more severe weather events to occur more often (AAS 2015). One lesson from the experience of Hurricane Katrina was to expect uncertainty in decision-making because every hazardous event brings unknown outcomes (Colten, Kates, and Laska 2008). 


\subsection{Policy networks and risk perception}

The risk environment is well known and described by key agencies that form the Policy Networks of food supply and disaster resilience. Examples include Australia's National Food Policy, which highlights the industry and government relationships and priorities for stabilising its domestic food systems. Additionally, the industry and government membership forms the food chain sector concerns for the Australian Government's Critical Infrastructure Resilience Strategy (CoA 2010, 17). These are the conventional food networks (Crowe and Smith 2012) and they represent a relative degree of symmetry and consensus within their particular issue network based on a relatively closed profile of sector-based policy communities ${ }^{1}$. On the upside, such networks acknowledge that national and transnational food networks entail the transportation of food products over large distances placing high dependence on transport infrastructure and fossil fuels, which is worrisome (CoA 2010; UKCO 2011).

On the downside, these Policy Networks are seen as particularly weak with regards to including communities in consultation and engagement outside of formal procedures for making suggestions and complaints (Ploger 2001) and formal channels of deliberations such as public hearings, meetings for discussions and debate, and the use of newspaper articles (Nyseth 2008). Acknowledging this weakness is important, as both the international and national disaster resilience policies have called for better preparation for disaster events, particularly at the community level (UNISDR 2016; COAG 2011).

\subsection{Governance networks and risk perception}

Governance Networks are defined as social mechanisms that entail activities such as gathering information, communication, decision-making and conflict resolution that influence the capacity for adaptations, coordination and exchanges within the network (Reis 2013). According to social network theory, these exchange relationships become ties that promote feelings of trust between members (Howes et al. 2014). As discussed in this article, local food networks are a relevant example (Crowe and Smith 2012).

According to groups within the local food network, governance failures ${ }^{2}$ of Policy Networks to anticipate how these complications and their uncertainties around engaging communities may be dealt with is seen as a further complicating factor of the risk environment (Reis 2013). In recognition of the need for adaptive and empowered communities, there is a trend of democratising food plans and contingency planning around that. This is compatible with emergent policy areas such as social inclusion, environmental sustainability and neighbourhood regeneration (Blanco, Lowndes, and Pratchett 2011) that are shaped by the dynamics of increasing social complexity, dynamism and diversity (Kooiman 2003). Local food networks call for more integrative approaches, given the social demands for an increased voice in decision-making and disenchantment with representative governance (Dalton 2005). In managing the risk environment, it is therefore important for local food networks to both build and share their knowledge and understanding about how they view the risks and sustainable ways of living with those risks (Burby et al. 1999).

The importance of deliberative consultation styles and issues of empowerment have recurred in the literature over some time (Arnstein 1969; Godschalk, Brody, and Burby 2003; Horney et al. 2015). However, adaptive and empowered communities that act upon their understandings of the risk environment will require people to feel that 
their government can be trusted and they will be fairly represented (Morrow 2008). For this reason, the role of local government and planning in general is not only important for shaping the form of the built environment (Gordon-Larsen et al. 2006) and reducing disaster risks (Sutanta, Rajabifard, and Bishop 2013; Ward Lyles, Berke, and Smith 2014), but in facilitating how communities may be empowered to participate in that process of shaping those built and risk environments for their enhanced food procurement in times of need (Campbell 1997, 2009; Creative Commons 2011; Parfitt et al. 2012; PHAA 2009; TFSC 2012).

Local governments in Queensland have responsibility for leading and enhancing community resilience (Queensland Government 2017). Resilient communities are characterised as having a high degree of social capacity to be self-reliant, adaptive and functioning well under stressful circumstances (COAG 2011). Australia's National Strategy for Disaster Resilience (NSDR) has a priority action of leading change and coordinating effort for disaster resilience (COAG 2011). Fundamental to this is facilitating engagement of communities built upon the aspirations of mutual trust and respect (CoA 2013). As such, the NSDR itself represents a shift towards the Governance Network approach to managing the risk environment.

\section{Methods}

This article addresses one issue that emerged from a broader research project that sought to explore the networks needed for urban food production spaces to function as sites for building community resilience and food security in times of crisis in SouthEast Queensland, Australia (Reis 2013). The broader study examined Australia's NSDR priority action of leading change and coordinating effort for disaster resilience. Three priority outcomes of this action were investigated including the following: 1) understanding the nature of the risk environment; 2) supporting community-based efforts and innovation that will enhance resilience; and 3) sharing responsibility for enhancing community resilience through partnerships and networks (COAG 2011). These three priority outcomes were methodically applied to a review and analysis of the literature to determine the opportunities and challenges at hand for local government, small-to-large-sized food businesses and community groups to facilitate this agenda. This article presents an aspect of that broader focus: How local governments, specifically, through the Governance Network approach (Blanco, Lowndes, and Pratchett 2011) can cut through these challenges and meet the opportunities head on, so that communities are best supported to act on their unique understanding of the risk environment (Burby et al. 1999; CoA 2013) and, hence, become more empowered and adaptive in their relationship to food security (FAO 2018) by building resilience of their communities to times of food scarcity (Sonnino 2017; Crowe and Smith 2012).

In terms of these three priority outcomes, the literature review of the broader study examined policies and plans of government bodies and non-government organisations and peer-reviewed research to clarify the points of agreement and disagreement in the research. The theorisation underpinning this interrogation of the literature was based upon Habermas's (1987) life-world ontology. The various ideological positions and generated discourses of the reviewed policies and peer-reviewed literatures demonstrated diverse life-worlds (and hence points of agreement and disagreement) that take place within any society that has differences (Welton 1995). The life-world is therefore an inter-subjective and integrated dynamic of where we live and have our experiences. 
The practical relevance of this theory is that it clarifies the role of discourses in the literature, and participants therefore contribute our knowledge of the efforts to reach understanding among them (Parkin 1996).

To corroborate the points of agreement and disagreement in the literature review, this theoretical framework was applied to interviews with practitioners working in the fields of disaster resilience, community education and advocacy, local government, school education and youth work. All participants were engaged with building community resilience and/or building access to local food. Purposive and snowball sampling (Yin 1992) was employed in the selection of participants based upon their roles among those fields. Initial communications with each practitioner were via email or telephone. Upon ethical clearance, the participants were questioned face-to-face with semi-structured interviews to produce newly generated empirical interview data. The interviews were recorded with consent and then thematicised using NVivo software. The results were then compared against the literature findings to draw conclusions on key themes, including the following: how risk perceptions and efforts to build community resilience are subject to various experiences as they are lived; the tensions experienced in worldviews about the legitimacy and efficacy of local food spaces for addressing food shortages; and recommended synergies between these dynamics for mobilising shared control.

This article presents the recommendations from these practitioners for local governments to help mobilise shared control of food access and availability with communities. Evidence from one interview question is explored: What should governments do to facilitate local food contingency plans? As presented in the following section, this article offers an exploration of their points of agreement. The quotes in this article are from 14 of the 17 participants of the broader study, with each individual assigned a descriptive job title that serves to protect the identity of the participant. Direct quotes from the interviewees are extensively used to show their own articulation of their particular life-world - that is, the "pre-reflective ground for our being in the world, which is given to us in the natural attitude and is taken for granted in everyday life" with the aim that the "natural attitude can be reflected upon and made visible" (Berndtsson et al. 2007, 259) in the imagination of you, the reader and the possibilities you might consider in your line of work.

\section{Results and discussion}

All 14 interviewees agreed that local contingency food plans can support local options for meeting food needs during and following a crisis. For example, Disaster Resilience Officer 3 suggested that local procurement has a place in disaster risk management: "They should have a local procurement policy or a local procurement provision... I think that that should be prioritised from a disaster-resilience and food-security point of view". The Officer further asserted that disaster contingency arrangements can be linked with local food planning: "I know they look at operational supply and re-supply from a disaster management point of view, but... as far as I'm aware, they haven't done food security contingency planning... It should be included in the local plan for food". The implications of this proposal are congruent with the NSDR, which acknowledges that more focus is needed on action-based resilience planning. This means that planning efforts should aim to strengthen local capacities and capabilities, and place a greater emphasis on community engagement to that end (CoA 2013). This will produce a better understanding of a community's diverse needs, strengths and 
areas of weakness (COAG 2011). It is also congruent with the Queensland Re-supply Guidelines on local re-supply options, whereby "all practical local options should be ruled out before a request for re-supply is passed" to authorities (EMQ 2012, 10). Based on the premise that local capacities should be strengthened before re-supply options are enacted, five key actions were identified:

1. Facilitate local food procurement policy within neighbourhood planning;

2. Disseminate a template of demonstrations to inform council planning and raise awareness of the broader public;

3. Facilitate shared control and responsibility with those who want it;

4. Change the rules and remove the barriers; and

5. Utilise policy that consults with and engages the broader community in decision-making.

\subsection{Facilitate local food procurement policy within neighbourhood planning}

Formal neighbourhood planning processes should embrace neighbourhood governance. The neighbourhood is a site for social, economic and ecological activity that brings people, groups and a variety of organisations together to shape the attributes of their locality (Somerville, Van Beckhoven, and Van Kempen 2009). All 14 interviewees agreed that local food procurement needs a formalised and planned approach to allow for this. School Educator 2 agreed that: "School and community gardens could supply fresh food to communities... We don't need to wait for a plan. However, it may be better organised within a formalised plan”. School Educator 2 called for a local government framework: "I'm interested to see how we can work within our local councils to develop a framework. So that we understand what's in our community and we understand where we can fit into it... It may open up a better, more transparent community if we had that sort of framework".

All 14 interviewees agreed that government officials, ministers and planners need to be politically brave enough to demonstrate leadership in local food procurement and contingencies. Community Educator and Advocate 2 suggested that there's "a role for government to be sufficiently well informed and politically brave enough to seed fund these kinds of educational activities". Local Government Officer 2 agreed and stated that: "I would love to see the government lead by example and make some radical decisions about urban food production". Local Government Officer 4 urged that the "political commitment is important... otherwise it doesn't follow through". This Officer further stated that a "tool to engage that political commitment... under the Local Government Act" is the requirement of councils "to develop long-term community plans [which are] informed by community engagement processes".

Community plans are fundamental to neighbourhood planning and provide the opportunity to identify values for both community health and economic well-being. Local Government Officer 4 further commented that: "one of the components that's incorporated in the community plan is around social wellbeing. So it gives the opportunity to say what do we mean by social wellbeing?" Furthermore, the same Officer asserted that: "in theory, if a community had identified ... food security issues" as part of their approach to social wellbeing, then: "the potential for that to be incorporated in the community plan is still there... a discussion would be within council, does that fall within council's remit and resources?" A policy avenue to dovetail with this is the 
emerging policy development in Australia of local social procurement policies (Victorian Government 2018). The platform sets out to formalise the process of integrating a range of local community health and economic well-being objectives. Chakraborty et al. (2011) urge that plans are more robust where they offer choices across contingency scenarios. In this case, a local procurement plan can be tailored to preferences of the authorities and residents of the time, for example:

- Shorter-term food enhancement or recovery for specific communities (Smith 2014). Disaster Resilience Officer 3 revealed that: "in disaster management, they have been funding community resilience and community organisations because they realise that they don't have the money to pay for recovery"; and/or

- Longer-term sustainability of community health and place-based economies (Berke and Conroy 2000) and climate change adaptation plans (Bassett and Shandas 2010; Freitag et al. 2014).

Whatever the choices, the trade-offs between those choices should be open to scrutiny, encourage involvement and consider future trajectories (Chakraborty and McMillan 2015). Disaster Resilience Officer 3 suggested that: "We should have local procurement strategies for all public institutions, as a percentage of their procurement... A percentage of that should come from the local area, because then it supports economic viability of local business. It just means that you're able to grow food locally and have it profitable".

Such statements support resilience-building activities which may be seen as indicating a greater measure of authentic resilience (Morrow 2008). Such activities will integrate consideration of sustainable, locally focused economics which are: "capable of supporting quality lifestyles... including meaningful jobs, adequate income, substantial housing, good education, access to health care, and safe neighbourhoods" (Mileti et al. 1995, 117). As Youth Worker and Educator 1 stated: "Keep it local... your local businesses, local council, local government, local organisations, local schools". Disaster Resilience Officer 1 concurred that local governments are: "more connected on the ground to individuals; it's less bureaucratic". Clearly councils and the planning profession have a role to play in neighbourhood planning that goes beyond stemming the issues with post-disaster recovery (Olshansky et al. 2008; Smith 2014).

\subsection{Disseminate a template of demonstrations to inform council planning and raise awareness of the broader public}

Networks of community innovation can be mapped to identify early adopters of local food procurement plans. Identifying these innovators and facilitators of community innovation can then foster community development (Balfour and Alter 2016). A study by Reis and Ferreira (2015) showed that demonstration projects can provide an avenue for councils to learn what works. As such, they can explore any opportunities and then promote that to other councils. Based on these learnings, a case study template could be devised to inform best practices.

Showcasing action learning within demonstration projects was highlighted as important. For example, School Educator 1 stated that the challenges are about: "maintaining that positive, visionary, goal-setting approach towards achieving outcomes... and celebrating that and then reviewing and renewing. Doing that action 
learning process". The concept of action learning, whereby the learning from small changes may be captured is consistent with the benefits of incremental, small steps which Lindblom (1979) argues, allows decisions to be made more quickly with less chance of antagonism. This is helpful given that many of these ideas "call into question a number of entrenched political and cultural attitudes about land, people, and ways of doing things that are in conflict with what actually needs to be done to achieve a quality-of-life and disaster-resistant society" (Geis and Kutzmark 2000, 4).

All 14 interviewees saw merit in the use of precedents to demonstrate to government and the public at large what has been achieved in the past. Community Educator and Advocate 1 found that Cuba's 26,000 self-provision gardens, which formed its local food procurement approach to the economic embargo of the 1980s: "was a profound lesson for us in what can be done". Local Government Officer 1 agreed that demonstrations are "a really good guide and a tool that helps others understand, oh it's not that hard! I could accommodate that, with a little bit of thought and effort. It just gives a whole variety of other ways that things can be brought in".

Local Government Officer 1 pointed out that the broader relevance of demonstrations can be used across government sector portfolios. For Disaster Resilience Officer 1 , however, it is hard to get people at large and within organisations behind change until there is sufficient pressure for them to engage with changes. This Officer further asserted that "you'd have to ... demonstrate it to most people that you're in really hard times - a bit like the water restriction. People can step up ... once they have it demonstrated". Some of the 14 interviewees cited the success of the water awareness raising campaign on changing behaviours ${ }^{3}$. Community Educator and Advocate 1 concurred that the success of this government education campaign on water is a good per cent for behaviour change: "I was stunned at how effective the water campaign was. It was the best example of a social change process based on giving people the facts, that I've come across, I think it's brilliant".

An analysis of three recent Australian disaster inquiries ${ }^{4}$ by Howes et al. (2012) revealed that programmes for raising community awareness is a well-established practice in disaster risk management. It is a particular strength of Policy Networks to disseminate better information to communities. In this way, they play an important role by making clear the complex circumstances that entail public deliberations (Bohman 1996) and promoting cooperative behaviour (Ali 2003). Local Government Officer 2 concurred that: "that's one of the roles that government plays in helping people making a good sound decision... and giving people the tools that they need to do it themselves".

\subsection{Facilitate shared control and responsibility with those who want it}

Issue networks are based on a relatively closed set of policy communities. Here, the focus is on a functional or policy anchor whereby "traditional policy fields at the national level, like agricultural, industrial or economic policy ... corresponds to the departmental boundaries of national governments" (Blanco, Lowndes, and Pratchett 2011, 301). Community Educator and Advocate 1 argued that: "an issue for the future is the extent to which governments will want to centralise control over the food production areas under emergency scenarios".

The NSDR argues that "strategy is the first step in a long-term, evolving process to deliver sustained behavioural change and enduring partnerships" (COAG 2011, ii). 
Governance Network literature allows us to see that emergent policy areas, such as the need for collaborative relationships, benefit from including the third-sector ${ }^{5}$ (Althaus, Bridgman, and Davis 2007; Nyholm and Haveri 2009). Citizen participation in plan making has a long history dating back to the 1950s (Brody, Godschalk, and Burby 2003). Interviewees agreed that local government should facilitate shared control and responsibility with Disaster Resilience Officer 1 arguing that: "one of the best things local government could do is to grease the wheels of community - existing community organisations. Not set up new things, just assist them". Community Educator and Advocate 3 supported this argument on government's facilitation of shared community control saying that because: "People often know the answers to their own problems... they're the doers in the end. That's where the creativity and the innovation lie". Community Educator and Advocate 4 also asserted that local food contingency should be "less prescriptive [and] actually allowing some space for the community to kick in with their own solutions". A community design approach has been found to improve localities (Morse Moomaw 2016). For example, upon envisioning alternative futures after Hurricane Katrina, Olshansky $(2006,151)$ calls for: "An energized environment for planning, taking advantage of a ... sense of purpose and civic pride" which, in turn, can produce innovative community design.

\subsection{Change the rules and remove the barriers}

Using streets as a way to bring relationships between humans and plants together in Montpellier, France, Pellegrini, and Baudry $(2014,871)$ argue: "that letting planted and unbidden flora colonize sidewalks and allowing people to act directly on it brings residents and plants to co-inhabit and co-domesticate the streets". This example demonstrates the importance of permitting people to act upon public spaces - spaces planned for residents by residents (Pellegrini and Baudry 2014, 875). Such practices are commonly referred to as guerrilla gardening (Spijker and Parra 2018) due to the subversive nature of altering a controlled public space.

This is important for the nature of policy making. As people attempt to address ongoing complex circumstances, such as relating more directly in greening the urban landscape (Pellegrini and Baudry 2014), both Policy Networks and Governance Networks are subject to the continual reorganising of governance styles and policy making (Blanco, Lowndes, and Pratchett 2011). Among the variety of models for measuring network performance, such as their efficiencies and effectiveness, is the question of appropriateness (Crossfield and Byrne 1994). That is, are the policy options for delivering government priorities appropriately consistent with, and continue to be consistent with, community needs? Local Government Officer 1 identified that: "We need to look at our own rules and regulations to say, well that's a barrier and it's a barrier for all the wrong reasons". Local Government Officer 1 continued that access to local food: "is important... we just need to start thinking about things differently and creatively, to be quite honest". An example provided by Local Government Officer 3 is that council needs to: "draw up new public liability to cover those... smaller groups. So they can go and have a garden and have council cover that cost... I was hoping that it could happen a lot sooner".

Land-use rights on public land are heavily constrained in Australian planning schemes. These arrangements set up rules for engagement that set up barriers to outsiders (Blanco, Lowndes, and Pratchett 2011). For example, planning for local food 
procurement is typically beset by: low levels of urban food awareness in land-use planning (Howe 2003); city officials' perceptions of gardens as a temporary use of vacant land (Francis 1987) and precariousness of land use due to the "whim of city planners" (Patel 1996, 45). Much of this leaves otherwise enthusiastic gardening groups with uncertainty and feelings of anxiety due to insecurity of tenure (Elder 2005) and the ongoing frustrations of dealing with the bureaucratic mindset in order to gain government support and funding (Jamison 1985).

Embracing the objectives of sustainability and environmentally focussed planning in general is valid, as are supporting activities through programmes and grants (Harris 2009). More specifically, the regulated and coordinated production of urban food in a formalised way through neighbourhood plans would be fruitful (Howe 2003). Local Government Officer 1 continued that the planning profession can: "help facilitate a different way the community can operate... Then, from a council officer perspective, having recognised that that's a good way forward, I can then maybe help get rid of some of those barriers and make it easier for people to come in and do the right thing later on".

A fruitful example of this desire can be observed as a new breed of urban and environmental planners emerge, and the utility of urban green-spaces is re-imagined (Rupprecht and Byrne 2014). Accordingly, some Australian councils have now adopted 'Verge Policies' with guidelines for growing food on the areas of public land located between a private property boundary, and the roadside (See Brisbane City Council 2017; City of Melbourne 2018). Shifting the discourse from that of subversive and illegal gardening, to that of minimizing safety hazards for pedestrians, and of ensuring species selection that does not obstruct the visibility of motorists, does indeed facilitate a more appropriate way the community can operate, should they wish to do so.

\subsection{Utilise policy that consults with and engages the broader community in decision making}

For people to trust that they are being treated fairly, decision-makers will need to involve them in decision-making about their own communities (Morrow 2008). Disaster Resilience Officer 3 agreed that local governments: "need to be more accountable and transparent than they are, in their processes". As Nyseth $(2008,499)$ argued, Policy Networks are often: "closed, elitist or narrow in their functional scope, accessible only to a small group of people". Additionally, they can drive complaints about their legitimacy because they lack transparency (Nyseth 2008). Well-meaning planners may also overlook participatory options when in a fast-paced and uncertain environment (Chandrasekhar, Zhang, and Xiao 2014). Disaster Resilience Officer 3 suggested that: "Community-controlled development should be something that's initiated by community [with] government as an external stakeholder supporter... Where government does engage with the community, it should do it in a transparent and accountable process, so that people feel like their input is actually taken on board, and they need to enter a more equal decision-making relationship with the community".

Community-centred decision-making requires that practitioners act as facilitators of other people's ideas. Providing avenues whereby communities may exercise their influence to reach outcomes that are meaningful to them is central to the facilitative process (Arnstein 1969). The need for more effective community consultation was agreed by interviewees. For example, Local Government Officer 4 stated that community consultation is: "Really, really important. From a council perspective... they [are] meant to 
develop a community engagement policy. The plans that they implemented [are] then meant to reflect the community engagement process". Many of the 14 interviewees agreed that government needs to participate as facilitators, not controllers, of community innovation. Community Educator and Advocate 4 agreed that government participation in planning for community initiatives should be one of facilitations and no more, stating that: "Creating community is something that a community creates, not a government department". Local Government Officer 2 believed that: "as someone who works in government with the community, the most important thing that I can do is enable people to do it themselves... I'm very fortunate in that we get really good face-to-face interaction with people". These interviewees articulated a clear need for facilitating the broader community in decision-making. As discussed next, they elaborated upon the importance of encouraging opportunities for engaging in casual conversations, trialling innovations in neighbourhood parliament and utilising participatory budgeting.

\subsubsection{Casual conversations}

Casual conversations can contribute to people's efforts to reach understanding between each other (Parkin 1996). Some interviewees noted the importance of community development officers in facilitating better face-to-face communication. For Disaster Resilience Officer 3, we: "need more community development officers for action on community development. They need to be prepared to interface with the community ... [to] respond to community members' needs, not being government-directed ... be more responsive". Local Government Officer 3 agreed that: "community development officers are fantastic in what they do" for community gardens because they "can gauge where they're coming from, get to know them as a community".

\subsubsection{Trialling neighbourhood parliament}

All interviewees agreed on the merit of government seed-funding of trials in communitybased innovations. Disaster Resilience Officer 2 provided precedents in government, business and non-government organisation (NGO) support of deliberative democracy and highlighted that: "Brazil, is a massive practitioner of deliberation, and the case studies out of that... was a particular town in Brazil - where, since 1993, they have invested $\$ 170$ million US dollars in a thousand projects all led by deliberation". Furthermore, Brazil is: "doing this at scale through the Internet... which reaches over a million people that have an opportunity to vote, to learn, to debate, to share ideas and projects. Like, how cool is that? That's pretty cool, right?" Community Educator and Advocate 4 made the following suggestion: "I think there's definitely scope at a local level to start trying these ideas out ... Bring people in to train people how to do it properly and just get them started and do a three-year trial of decision-making ... it just depends on the will of the council... the perfect place to trial it, is to develop a local area plan for that community".

\subsubsection{Participatory budgeting}

Participatory budgeting is about communities sharing in the budgeting of their own projects and tailoring the engagement to the outcome of the project. Disaster Resilience Officer 2 advocated that participatory budgeting worked well in the series of town hall proposals, meetings and debates initiated by a local councillor for 
Brooklyn who allocated a million dollars out of the operating budget for the community to decide how to spend. They reported that: "they came up with five projects that are each around $\$ 200,000$. One of them is an urban garden, and one of them is a compost facility outside of a major high school". Community Educator and Advocate 4 asserted that one of the main problems is that people "don't feel like they've got permission to do that", stating further that: "If there's anything that governments could do it's to actually say hey, if you've got an idea to create something or to innovate or provide a solution for your community, then here are some funds you can access to help you do that". Disaster Resilience Officer 2 recommended: "Do it as an experiment... you will see the wisdom of the public if they are informed and allowed to engage. They will come back with practical comments and ideas, and that very engagement builds resilience about who we are and what our priorities are, and how we connect to each other... and having a relationship to where your taxes go".

\section{Concluding thoughts and recommendations for the future}

The NSDR agenda is for a shared responsibility to build resilience at the government, business, neighbourhood and community levels (COAG 2011). This article examined how local food procurement arrangements and contingency plans based on this arrangement can ameliorate food shortage under the direction of government leadership. This was situated in the context of the South-East region of the State of Queensland, Australia. An important feature of the shared responsibility framework is the need for a "better understanding of the risk environment and disaster impacts, and an adaptive and empowered community that acts on this understanding" (COAG 2011, 3). It was argued that this call falls well within the remit of local food procurement planning given the Emergency Management Queensland, the department responsible for managing emergency re-supply, stated that: "All practical local options should be ruled out before a request for re-supply is passed" to authorities (EMQ 2012, 10).

How adaptive communities can act on their understanding of the risk environment was explored in terms of the conventional Policy Networks based upon government and industry alliances and the alternative Governance Networks based upon third sector groups that sit outside the conventional network relationships. These alternative networks were found to be largely disempowered to act upon their own local community-based initiatives that can lead to more coordinated and planned arrangements for food contingencies. A call for more active participation in the design and shaping of communities was entertained.

Drawn from a broader research project, this article addressed what governments can do to facilitate local food contingency plans. Evidence from 14 practitioners were presented based upon their relationships among the fields of disaster resilience, community education and advocacy, local government, school education and youth work. Interview data and a review of the literature from the broader study revealed five key actions:

1. Facilitate local food procurement policy within neighbourhood planning;

2. Disseminate a template of demonstrations to inform council planning and raise awareness of the broader public;

3. Facilitate shared control and responsibility with those who want it;

4. Change the rules and remove the barriers; and

5. Utilise policy that consults with and engages the broader community in decision-making. 
The practitioners interviewed in this study were well aware that shared responsibility for building community resilience does not mean equal responsibility. Interviewees primarily viewed institutional agents as having a greater share in the responsibility as far as creating the conditions that will allow people to participate in decision-making and act on their own creative initiatives. Fahlquist $(2009,111)$ states that: "Individuals who have reasonable alternatives, capacity and resources to do something... should be seen as responsible. Institutional agents have the power and resources to affect the number of individuals who possess such capacity and resources".

In the light of the richness of the interview data presented here and its resonance with the literature, the government practitioners interviewed, in particular, where acutely aware of the discrepancy between progressive policies in their workplaces such as the NSDR and the slow pace in meeting those goals. These interviewees were articulate, well informed and passionate advocates within their line of work and were quite eager to do more on the local food procurement front. For example, Local Government Officer 2 revealed that: "I would like to be doing a lot more. I always want to do more for everything, whether it's local food, carbon emissions, or protecting our waterways; that's the nature of the work that I do particularly".

The creative and motivating role of champions for leading changes in the workplace is not to be ignored (Juravle and Lewis 2009). Champions, by virtue of their passion and enthusiasm, are found to be better positioned to help people make connections between key projects and initiatives that could be overlooked (Howes et al. 2014). The five actions offered will be of relevance to practitioners in government and community groups who may find their own unique ways to champion local food contingency planning in their area of interest.

\section{Notes}

1. Blanco, Lowndes, and Pratchett (2011) identify that Policy Networks arose from traditions in the 1960s in the UK and the USA, such as policy communities and issue networks. Policy Networks operate within policy domain-specific subsystems where there is a relative visibility of policy issues and outcomes and the expectations of its select members. This is a longstanding and standard feature of policy-making as they are "really" made $(2011,298)$.

2. The term governance relates to the exercise of authority and control; and governing involves the right to exercise influence and authority (Delbridge and Bernard 1998).

3. This water education example refers to a successful campaign by the Queensland State government during the 2001-09 drought that encouraged people to more than halve their water usage by adopting simple conservation measures.

4. The inquiries included: The Victorian Bushfires Royal Commission, the Perth Hills Bushfire Review and the Queensland Floods Commission of Inquiry.

5. Lyons $(2001,5)$ comprises the third sector as: Non-Government Organisations (NGOs); the social economy or civic society; non-profit, community-driven and voluntary sectors; and lobby and interest groups. According to Lyons (cited in Althaus, Bridgman, and Davis 2007,18 ), such organisations are characteristically: "private; formally organised; derived from collective action and generating common values and benefits; voluntary in membership; not seeking personal profit; and usually democratically controlled".

\section{Acknowledgement}

This work was supported by Griffith University under the Griffith University Postgraduate Research Scholarship. 


\section{Disclosure statement}

No potential conflict of interest was reported by the author.

\section{References}

Ali, S. 2003. "Environmental Planning and Cooperative Behaviour: Catalysing Sustainable Consensus." Journal of Planning Education and Research 23 (2): 165-176.

Althaus, C., P. Bridgman, and G. Davis. 2007. The Australian Policy Handbook. 4th ed. Crows Nest, NSW: Allen and Unwin.

Arnstein, S. 1969. "A Ladder of Citizen Participation." Journal of the American Institute of Planners 35 (4): 216-224.

AAS (Australian Academy of Science). 2015. The Science of Climate Change: Questions and Answers. Canberra: Australian Academy of Science. https://www.science.org.au/files/userfiles/ learning/documents/climate-change-r.pdf.

AIDR (Australian Institute for Disaster Resilience). 2018. Australian Disaster Resilience Disaster Knowledge Hub. Canberra: Australian Institute for Disaster Resilience. https:// knowledge.aidr.org.au/collections/handbook-collection/.

Balfour, B., and T. Alter. 2016. "Mapping Community Innovation: Using Social Network Analysis to Map the Interactional Field, Identify Facilitators, and Foster Community Development." Community Development 47 (4): 431-448.

Bassett, B., and V. Shandas. 2010. "Innovation and Climate Action Planning." Journal of the American Planning Association 76 (4): 435-450.

Berke, P., and M. Conroy. 2000. "Are We Planning for Sustainable Development? An Evaluation of 30 Comprehensive Plans." Journal of the American Planning Association 66 (1): 21-33.

Berndtsson, I., S. Claesson, F. Friberg, and J. Ohlen. 2007. "Issues about Thinking Phenomenologically While Doing Phenomenology." Journal of Phenomenological Psychology 38 (2): 256-277.

Blanco, I., V. Lowndes, and L. Pratchett. 2011. "Policy Networks and Governance Networks: Towards Greater Conceptual Clarity." Political Studies Review 9 (3): 297-308.

Bohman, J. 1996. Public Deliberation: Pluralism, Complexity and Democracy. Cambridge, MA: MIT Press.

Brisbane City Council. 2017. Verge Gardens. Brisbane City Council. https://www.brisbane.qld. gov.au/environment-waste/natural-environment/plants-trees-gardens/verge-gardens.

Brody, S., D. Godschalk, and R. Burby. 2003. "Mandating Citizen Participation in Plan Making: Six Strategic Planning Choices." Journal of the American Planning Association 69 (3): 245-264.

Burby, R., Beatley, T. P. Berke, R. Deyle, S. French, D. Godschalk, E. Kaiser, J., et al. 1999. "Unleashing the Power of Planning to Create Disaster-Resistant Communities." Journal of the American Planning Association 65 (3): 247-258.

Campbell, A. 2009. Paddock to Plate: Policy Propositions for Sustaining Food and Farming Systems: The Future Food and Farm Project Propositions Paper. Melbourne: Australian Conservation Foundation. https://www.researchgate.net/publication/236627337_Paddock_to_ Plate_policy_propositions_for_sustaining_food_farming_systems.

Campbell, D. 1997. "Community-Controlled Economic Development as a Strategic Vision for the Sustainable Agriculture Movement." American Journal of Alternative Agriculture 12 (01): 37-44.

City of Melbourne. 2018. Street Garden Guidelines. City of Melbourne: https://www.melbourne. vic.gov.au/residents/home-neighbourhood/gardens-and-green-spaces/Pages/street-gardenguidelines.aspx.

Colten, C., R. Kates, and S. Laska. 2008. "Three Years after Katrina: Lessons for Community Resilience." Environment: Science and Policy for Sustainable Development 50 (5): 36-47.

CoA (Commonwealth of Australia). 2010. Critical Infrastructure Resilience Strategy. Barton, ACT: Australian Government, Attorney General's Department. https://www.tisn.gov.au/ Documents/Australian \pm Government $\pm \mathrm{S} \pm$ Critical \pm Infrastructure \pm Resilience \pm Strategy.pdf.

CoA (Commonwealth of Australia). 2013. National Strategy for Disaster Resilience: Community Engagement Framework. Handbook 6. Barton, ACT: Australian Government, Attorney 
General's Department. https://knowledge.aidr.org.au/media/1761/handbook-6-nationalstrategy-for-disaster-resilience-kh-final.pdf.

COAG (Council of Australian Governments). 2011. National Strategy for Disaster Resilience: Building Our Nation's Resilience to Disasters. Barton, ACT: NEMC Working Group tasked by the COAG. https://www.ag.gov.au/EmergencyManagement/Documents/NationalStrategyfor DisasterResilience.PDF.

Chakraborty, A., N. Kaza, G. Knaap, and B. Deal. 2011. "Robust Plans and Contingent Plans." Journal of the American Planning Association 77 (3): 251-266.

Chakraborty, A., and A. McMillan. 2015. "Scenario Planning for Urban Planners: Toward a Practitioner's Guide." Journal of the American Planning Association 81 (1): 18-29.

Chandrasekhar, D., Y. Zhang, and Y. Xiao. 2014. "Nontraditional Participation in Disaster Recovery Planning: Cases from China, India, and the United States." Journal of the American Planning Association 80 (4): 373-384.

Creative Commons. 2011. Resetting the Table: A People's Food Policy for Canada. Montreal, QC: Food Secure Canada. https://foodsecurecanada.org/sites/foodsecurecanada.org/files/ FSC-resetting2012-8half11-lowres-EN.pdf.

Crossfield, L., and A. Byrne. 1994. Review of the Evaluation Function in DEET. Canberra: Department of Employment, Education and Training AGPS.

Crowe, J., and J. Smith. 2012. "The Influence of Community Capital toward a Community's Capacity to Respond to Food Insecurity." Community Development 43 (2): 169-186.

Dalton, R. 2005. Democratic Challenges, Democratic Choices: the Erosion of Political Support in Advanced Industrial Democracies. Oxford: Oxford University Press.

Delbridge, A. and J. Bernard. Eds. 1998. The Macquarie Concise Dictionary. 3rd ed. Macquarie: Macquarie University.

Elder, R. 2005. "Protecting New York City's Community Gardens." N.Y.U. Environmental Law Journal 13: 769-800.

EMQ (Emergency Management Queensland). 2012. Queensland Re-supply Guidelines. Brisbane: State of Queensland. http://www.disaster.qld.gov.au/dmp/Archive/Documents/Queensland\%20 Resupply\%20Guidelines.pdf.

Fahlquist, J. 2009. "Moral Responsibility for Environmental Problems: Individual or Institutional?" Journal of Agricultural and Environmental Ethics 22 (2): 109-124.

FAO (Food and Agriculture Organisation of the United Nations). 2018. Food Security Statistics. Rome: FAO. http://www.fao.org/economic/ess/ess-fs/en/.

Francis, M. 1987. "Meanings Attached to a City Park and a Community Garden in Sacramento." Landscape Research 12 (1): 8-12.

Freitag, R., D. Abramson, M. Chalana, and M. Dixon. 2014. "Whole Community Resilience: An Asset-Based Approach to Enhancing Adaptive Capacity Before a Disruption." Journal of the American Planning Association 80 (4): 324-335.

Geis, D., and T. Kutzmark. 2000. "Developing Sustainable Communities.” Public Management 77(August): 4-13.

Godschalk, D., S. Brody, and R. Burby. 2003. "Public Participation in Natural Hazard Mitigation Policy Formation: Challenges for Comprehensive Planning." Journal of Environmental Planning and Management 46 (5): 733-754.

Gordon-Larsen, P., M. Nelson, P. Page, and B. Popkin. 2006. "Inequality in the Built Environment Underlies Key Health Disparities in Physical Activity and Obesity." Pediatrics 117 (2): 417-424.

Green Cross. 2018. Empowering a Resilient Australia. https://www.greencrossaustralia.org/.

Guitart, D., J. Byrne, and C. Pickering. 2015. "Greener Growing: Assessing the Influence of Gardening Practices on the Ecological Viability of Community Gardens in South East Queensland, Australia." Journal of Environmental Planning and Management 58 (2): $189-212$.

Habermas, J. 1987. Theory of Communicative Action. Volume Two: Lifeworld and System: a Critique of Functionalist Reason. Translated by Thomas McCarthy. Boston, MA: Beacon Press.

Harris, E. 2009. "The Role of Community Gardens in Creating Healthy Communities." Australian Planner 46 (2): 24-27.

Horney, J., M. Simon, S. Grabich, and P. Berke. 2015. "Measuring Participation by Social Vulnerable Groups in Hazard Mitigation Planning, Bertie County, North Carolina.” Journal of Environmental Planning and Management 58 (5): 802-818. 
Howe, J. 2003. "Growing Food in Cities: The Implications for Land-Use Policy." Journal of Environmental Policy and Planning 5 (3): 255-268.

Howes, M., D. Grant-Smith, K. Reis, P. Tangney, K. Bosomworth, M. Heazle, D. McEvoy, and P. Burton. 2012. The Challenge of Integrating Climate Change Adaptation and Disaster Risk Management: Lessons from Bushfire and Flood Inquiries in an Australian Context. Issues Paper 17, September. Brisbane, Australia: Urban Policy Program, Griffith University.

Howes, M., P. Tangney, K. Reis, D. Grant-Smith, M. Heazle, K. Bosomworth, and P. Burton. 2014. "Towards Networked Governance: Improving Interagency Communication and Collaboration for Disaster Risk Management and Climate Change Adaptation in Australia." Journal of Environmental Planning and Management 58 (5):1-20.

IFRC (International Federation of Red Cross and Red Crescent Societies). 2012. Contingency Planning Guide. Geneva: IFRC. http://www.ifrc.org/PageFiles/40825/1220900-CPG\%202012EN-LR.pdf.

Jamison, M. 1985. "The Joys of Gardening: Collectivist and Bureaucratic Cultures in Conflict." The Sociological Quarterly 26 (4): 473-490.

Juravle, C., and A. Lewis. 2009. "The Role of Championship in the Mainstreaming of Sustainable Investment (SI): What Can We Learn from SI Pioneers in the United Kingdom?" Organisation and Environment 22 (1): 75-98.

Kato, Y., and L. McKinney. 2015. "Bringing Food Desert Residents to an Alternative Food Market: A Semi-Experimental Study of Impediments to Food Access." Agriculture and Human Values 32 (2): 215-227.

Kooiman, J. 2003. Governing as Governance. London: Sage.

Lindblom, C. 1979. "Still Muddling, Not Yet Through." Public Administration Review 39 (6): $517-526$.

Lyons, M. 2001. Third Sector: The Contribution of Nonprofit and Cooperative Enterprise in Australia. Crows Nest, NSW: Allen and Unwin.

Morrow, B. 2008. Community Resilience: A Social Justice Perspective. CARRI Research Report 4. Oak Ridge, USA: Community and Regional Resilience Initiative, National Security Directorate.

Morse Moomaw, S. 2016. "Improving Local Results: Fusing Community Design and Community Development." Community Development 47 (5): 670-682.

Mileti, D., J. DeRouen Darlington, E. Passerini, B. Forrest, and M. Myers. 1995. "Toward an Integration of Natural Hazards and Sustainability." The Environmental Professional 17 (2): $117-126$.

Nyholm, I., and A. Haveri. 2009. "Between Government and Governance: Local Solutions for Reconciling Representative Government and Network Governance." Local Government Studies 35 (1): 109-124.

Nyseth, T. 2008. "Network Governance in Contested Urban Landscapes." Planning Theory and Practice 9 (4): 497-514.

Olshansky, R. 2006. "Planning after Hurricane Katrina." Journal of the American Planning Association 72 (2): 147-153.

Olshansky, R., L. Johnson, J. Horne, and B. Nee. 2008. "Longer View: Planning for the Rebuilding of New Orleans." Journal of the American Planning Association 74 (3): 273-287.

Parfitt, C., N. Rose, M. Croft, and J. Alden. 2012. A People's Food Plan. Australian Food Sovereignty Alliance. http://afsa.org.au/blog/tag/peoples-food-plan/.

Parkin, A. 1996. "On the Practical Relevance of Habermas's Theory of Communicative Action." Social Theory and Practice 22 (3): 417-441.

Patel, I. 1996. "Rutgers Urban Gardening: A Case Study in Urban Agriculture." Journal of Agricultural and Food Information 3 (3): 35-46.

Pellegrini, P., and S. Baudry. 2014. "Streets as New Places to Bring Together Both Humans and Plants: Examples from Paris and Montpellier (France)." Social and Cultural Geography 15 (8): 871-900.

Ploger, J. 2001. "Public Participation and the Art of Governance." Environment and Planning B: Planning and Design 28: 219-241.

Pooley, J., L. Cohen, and L. Pike. 2005. "Can Sense of Community Inform Social Capital?" The Social Science Journal 42 (1): 71-79.

PHAA (Public Health Association Australia). 2009. A Future for Food: Addressing Public Health, Sustainability and Equity from Paddock to Plate. Curtin, ACT: Public Health Association Australia. http://www.phaa.net.au/documents/PHAA\%20Report.pdf. 
QCOSS (Queensland Council of Social Services). 2012. What is Community Resilience in Queensland? Brisbane: State of Queensland. http://www.communityindicatorsqld.org.au/.

Queensland Government. 2017. Queensland Strategy for Disaster Resilience 2017: Making Queensland the Most Disaster Resilience State in Australia. Brisbane: State of Queensland. http://qldreconstruction.org.au/u/lib/cms2/QLD-Strategy-for-Disaster-Resilience.pdf.

QRA (Queensland Reconstruction Authority). 2017. Prepare for Evacuation. From the 'Get Ready Queensland' Program. Brisbane: State of Queensland. https://getready.qld.gov.au/ plan/step-2-emergency-and-evacuation-kits/.

Reis, K. 2013. "Food for Thought: The Governance of Garden Networks for Building Local Food Security and Community-Based Disaster Resilience.” PhD Diss. Griffith University, Brisbane. https://research-repository.griffith.edu.au/handle/10072/366226.

Reis, K., and J. Ferreira. 2015. "Community and School Gardens as Spaces for Learning Social Resilience." Canadian Journal of Environmental Education 20: 63-77. https://cjee.lakeheadu. ca/article/view/1341/843.

Rupprecht, C., and J. Byrne. 2014. "Informal Urban Greenspace: A Typology and Trilingual Systematic Review of its Role for Urban Residents and Trends in the Literature." Urban Forestry and Urban Greening 13 (4): 597-611. doi:10.1016/j.ufug.2014.09.002.

Smith, G. 2014. "Involving Land Use Planners in Pre-Event Planning for Post-Disaster Recovery." Journal of the American Planning Association 80 (4): 306-307.

Somerville, P., E. Van Beckhoven, and R. Van Kempen. 2009. "The Decline and Rise of Neighbourhoods: The Importance of Neighbourhood Governance." International Journal of Housing Policy 9 (1): 25-44.

Sonnino, R. 2017. "The Cultural Dynamics of Urban Food Governance." City, Culture and Society (Forthcoming). doi:10.1016/j.ccs.2017.11.001.

Spijker, S., and C. Parra. 2018. "Knitting Green Spaces with the Threads of Social Innovation in Groningen and London." Journal of Environmental Planning and Management 61 (5-6): $1011-1032$.

Sutanta, H., A. Rajabifard, and I. Bishop. 2013. "Disaster Risk Reduction Using Acceptable Risk Measures for Spatial Planning." Journal of Environmental Planning and Management 56 (6): 761-785.

TFSC (Tasmanian Food Security Council). 2012. Food for All Tasmanians: A Food Security Strategy. Hobart: Tasmanian Government. http://www.dpac.tas.gov.au/_data/assets/pdf_file/ 0005/159476/Food_for_all_Tasmanians_-_A_food_Security_Strategy.PDF.

UKCO (United Kingdom Cabinet Office). 2011. Strategic National Framework on Community Resilience. London: Cabinet Office. https://www.gov.uk/government/publications/communityresilience-resources-and-tools.

UNISDR (United Nations Office for Disaster Risk Reduction). 2016. UNISDR Strategic Framework 2016-2021. Geneva: United Nations Office for Disaster Risk Reduction. https:// www.unisdr.org/files/51557_strategicframework.pdf.

Victorian Government. 2018. Social Procurement Toolkit. Melbourne, Australia: Department of Planning and Community Development. https://www.localgovernment.vic.gov.au/strengtheningcouncils/procurement/social-procurement.

Ward Lyles, L., P. Berke, and G. Smith. 2014. "Do Planners Matter? Examining Factors Driving Incorporation of Land Use Approaches into Hazard Mitigation Plans." Journal of Environmental Planning and Management 57 (5): 792-811.

Welton, M. 1995. In Defense of the Lifeworld: Critical Perspectives on Adult Learning. Albany: State University of New York Press.

Yin, R. 1992. "The Case Study Method as a Tool for Doing Evaluation." Current Sociology 40 (1): 121-137. 